\title{
Effects of Outsourcing on National Forest Plantation Development Programme in Ghana
}

\author{
Charles Adusei ${ }^{1}$, Abdul Karim Seidu ${ }^{2} \&$ Jasper Yao Dunyah ${ }^{2}$ \\ ${ }^{1}$ Department of Accounting, Finance and Banking, Garden City University College, Kumasi, Ghana \\ ${ }^{2}$ Forest Services Division of Forestry Commission, Atebubu, Brong-Ahafo Region, Ghana \\ Correspondence: Charles Adusei, Department of Accounting, Finance and Banking, Garden City University \\ College, Kumasi - Ghana. P. O. Box KS 6033. Kumasi - Ghana. Tel: 233-24-829-0734.
}

Received: January 7, 2017

Accepted: March 7, 2017

Online Published: March 14, 2017

doi:10.20849/abr.v2i1.125

URL: https://doi.org/10.20849/abr.v2i1.125

\begin{abstract}
The study aimed at management of outsourcing of National Forest Plantation Development Programme (NFPDP) and its effects in the Atebubu Forest District as a case study in Ghana. The key issues examined are the level of technical competence of the contractors, the role of the lead implementing agency and the natural resource base sustainability. Two stage sampling technique was used to sample one hundred and ten respondents for the study. A structured questionnaire was used to solicit information from the respondents. Descriptive and inferential statistics were used to analyse the data. The results of the study indicate that the award of seedlings contracts and workers' salaries and logistics to African Foresters Brigade and Zoil Ghana Limited respectively were transparent. However, most of the activities the participating institutions performed were behind schedule indicating poor performance. It is therefore recommended that, Forestry Commission should put in place proper modalities to ensure effective implementation if outsourcing is to be continued.
\end{abstract}

Keywords: outsourcing, national forest plantation development programme, forestry, Ghana

JEL: C42, Q23

\section{Introduction}

The Forestry Sector Plantation Activities keep growing globally due to global warming and maintenance of the industry supplies to the timber market. Limited resources, diffusion of global knowledge and cost reduction in executing plantation activities have driven the sector into outsourcing. It is against this background that the National Forest Plantation Development Programme (NFPDP) was first launched in 2001 by the Government of Ghana with the following key objectives: - to restore the forest cover of degraded land, to generate employment, to address future wood deficit and enhanced food production. Field implementation of the programme took place in between 2002 and 2009; the programme coverage was on the on-reserve forest areas.

However, in January 2010, the programme was re-launched to include off-reserve areas to benefit from the programme and expanded to give it a nationwide coverage. This new programme expanded the coverage to include the establishment and maintenance of plantations outside Forest Reserves on private lands. Additionally, the objectives under the NFPDP were expanded to include positioning the programme to secure carbon credits and payment for environmental services. There was also an institutional arrangement for smooth implementation of this programme. Under this arrangement, Ministry of Lands and Natural Resources (MLNR) was to provide the overall policy direction for the programme with Forestry Commission (FC) being the lead implementing agency. Other collaborating agencies in the programme implementation included; the private sector, Metropolitan/Municipal/District Assemblies (MMDAs), Non-Governmental Organization (NGOs), Forestry Research Institute of Ghana (FORIG),Traditional Authorities/Land Owners and other Agencies.

In 2010, the NFPDP outsourced forest plantation for the first time in the history of Forestry Commission where ZOIL GH Ltd and African Forester Brigade Ltd were selected to execute the programme with the former taking charge of workers' salaries and logistics while the latter was responsible for seedlings supplies. The key responsibilities of the various institutions engaged in the NFPDP are indicated in the Table 1 below. 
Table 1. Institution responsibilities

\begin{tabular}{|c|c|}
\hline Institution & Key Responsibilities \\
\hline \multirow[t]{2}{*}{ Ministry of Lands and Natural Resources. } & Policy formulation and direction \\
\hline & Overall Monitoring and Evaluation (Policy Level) \\
\hline Forestry Commission & Lead Implementing Agency \\
\hline ZOIL GH Ltd, & $\begin{array}{l}\text { Execution of Contracts -recruitment and payment of salaries and } \\
\text { plantation establishment }\end{array}$ \\
\hline African Foresters Brigade Ltd & Execution of Contracts- seedlings supplies \\
\hline \multirow{2}{*}{$\begin{array}{l}\text { Metropolitans } \text { Municipals and } \text { District } \\
\text { Assemblies }\end{array}$} & Facilitate land identification and negotiation (OFR) \\
\hline & Facilitate recruitment of labour \\
\hline Landowners & Provide land \\
\hline Non-Governmental Organizations & Awareness creation \\
\hline Forestry Research Institute of Ghana & Monitoring \\
\hline Ghana National Fire Service & Fire management (Suppression) \\
\hline
\end{tabular}

This study aimed at management of outsourcing of NFPDP and its effects in the Atebubu Forest District.

\section{Literature Review}

\subsection{Outsourcing-Theoretical Review}

According to Quelin and Duhamel (2003) outsourcing is defined as the operation of taking a transaction initially handled internally to an external party through a long-term contract. They added that it concerns transfer of staff to the service provider. Quelin and Duhamel (2003) argue that outsourcing helps the organisation concentrates on its core competence and that this can create a competitive advantage for the outsourcing firm. Corbett (2004) asserted that to outsource, a firm needs to know its business core identity. He indicated further that by knowing one's own unique competitive advantage, one is well placed to decide what task the firm is doing that other firms could perform better. Organisations strategically take outsourcing decisions because they want to concentrate on their core competence (Weerakkody and Curries, 2003). They added that if organisations focus on their core competence it leads to improvement in business focus, increase in competitiveness and as well as leveraging the firm's skills and resources. They concluded that this can enhance customer satisfaction.

According to Brown and Wilson (2005) organisations make outsourcing decisions in order to reduce cost. They stated that outsourcing decisions is about improvement in profit, operating efficiency and also adding value to the product. Gonzalez et al. (2005) also confirmed that cost reduction motivates organization and industries to make outsourcing decisions. Furthermore, most organizations choose to outsource some of their activities in order to minimize capital investment with the view of achieving availability of capital funds for core activities which are so critical to the industry and to improve return on assets (Clott, 2004). Corbett (2004) asserted that organisations are driven into making outsourcing decisions because of their desire to accelerate business process re-engineering to create a competitive advantage. Jennings, (2002) rather was of the view that capability of suppliers drives companies to making outsourcing decisions. He said that this will create room for partnering which leads to improve service quality, customer service and increase competitive advantage.

Lonsdale and Cox (2000) stated that losing core activities is the most significant risk of outsourcing. They claim that loss of core activities can arise from management's primary motive of cutting down cost in the short-term or head count reduction which might blind fold them into unintentionally outsourcing a core activity. They added that even suppliers can mislead management by first offering over optimistic cost savings which can influence management in outsourcing a core activity. Outsourcing can lead to loss of knowledge and skills as suggested by Heywood (2001). It is argued that if a firm ceases to conduct an activity, knowledge and skills related to that activity are lost. McIvor (2005) indicated that knowledge loss does not happen overnight but over the years. Burkholder (2006) also supported the assertion and said that if a company outsources so much of its functions that company stands to be hollow. 


\subsection{The Management of Outsourcing Implementation-before and after Outsourcing}

Once an organisation has settled to proceed with the outsourcing then it has to manage the outsourcing process. Barthelemy (2003) asserted that management approaches to outsourcing are of two distinct categories such as hard and soft. He said that the hard management approach is emphasizing on the significance of contracts and other agreements, whereas the soft management refers to the outsourcing organisation creating a relationship with the vendor. Firms seeking for outsourcing relationship must establish mutual commitment and trust.

Two issues are involved in the management of outsourcing implementation process and these are the pre-implementation process known as ex ante and the implementation process also known as ex post.

\subsubsection{Ex-ante Implementation}

The ex-ante implementation management has to deal with activities that precede the initiation of the outsourcing. For instance internal reorganisation, external supplier search and selection form part of the ex-ante activities. Heywood (2001) argued that though certain activities are of high asset specific it was also possible for companies to take certain actions that could decrease the asset specificity. Modularisation is one of the key strategies which can be used to decrease asset specificity of an activity at the same time improve its transferability. According to Mikkola (2003) modularisation of products and processes plays a crucial role in the outsourcing process. Modularisation reflects the extent to which the products and production processes are decomposed into smaller sub-systems and activities which are designed and managed separately yet function as a whole (Mikkola, 2006).

However, (Burkholder, 2006) also indicated that different criteria in supplier selection prevail in different phases. It is argued that what is being outsourced, determines the supplier selection criteria. According to (Hoetker, 2005) when innovative components are sourced, the technical level of the supplier is the critical criterion. Again, asset specificity according to (Mol et al., 2004) compels companies to seek for highly specialized supply sources and to assess supplier accordingly. It is also said that if the outsourcing does not require high skills from the supplier, then other criteria such as price becomes critical.

Heywood (2001) gave a general view that for outsourcing to be successful, the company needs to measure the important characteristics and evaluate the suppliers based on the specification they so desire to achieve. Having identified the prospective supplier a contract has to be drawn by the company. This should include functional requirements of the outsource task and terms dictating vendor-evaluation requirements with clear quality and effectiveness objective (Platz and Temponi, 2007).

\subsubsection{Ex-post Implementation}

Ex post management has to do with vendor relationship and the tasks involved. It is made up of two different phases. These are project/process transfer and project/process management. The transfer has to do with how to manage the movement of production to the vendor. This is followed by the task of managing the on-going outsourcing process.

Concerning transfer management it was argued that it can be one-time event or better still incremental. Failure to transfer outsourcing or any delay in its transfer can have negative impact on the total performance or can even lead to relationship dissolution before the process takes off. The degree of collaboration at this stage will depend not only on the embedded asset specificity of the activity but also on the success of the internal product. The significance of activity related knowledge transfer to the vendor has gained currency in research (Click and Dueing, 2005). According to Morgan (2003) establishing relationship and putting in procedures for the day-to-day management of the outsource function with the vendor are crucial in achieving the outsourcing objective. Morgan (2003) added that the key issue behind the success of outsourcing deals is the management of outsourcing relations.

Much of the literature claims that outsourcing helps organisation's to concentrates on its core competencies (Quelin and Duhamel, 2003; Corbett, 2004; Weerakkody and Curries, 2003). In terms of outsourcing reducing cost authors such as (Brown and Wilson, 2005; Gonzalez et.al., 2005; and Clott, 2004) highlighted its advantage. For outsourcing to be beneficial to organisations as indicated by Corbett (2004) an organization must know its business core identity while Weerakkody and Curries (2003) affirmed that it leads to improvement in business focus. Given the importance of outsourcing and its advantages to organization's operations and performance, it is critical that organization must not only focus in the advantages but also consider the challenges as well for a practical and holistic decision making on the outsourcing. This assertion were the concerns of researchers such as (Lonsdale and Cox, 2000; Heywood, 2001; McIvor, 2005; and Burkholder, 2006) all made mention of significant risk of outsourcing. 
A lot of researchers such as (Heywood, 2001; Mikkola, 2003; Burkholder, 2006; Hoetker, 2005; and Platz and Temponi, 2007) had diverse views on the Ex-ante implementation of outsourcing and whereas (Click and Dueing, 2005; and Morgan, 2003) were concerned about Ex-post implementation. For the management of outsourcing to be effective, a conscious effort must be put in place before, during and after its implementation as an ongoing activity for review and reconsideration in line with the purpose of the outsourcing whether it is on track. Forestry is different from managing a company as its stakeholders are diverse and sparsely geographically so its management needs more resources in terms of competent personnel and logistics via strict supervision and monitoring of staff and players within the forestry. While most researchers elaborated on the advantages of outsourcing in general, the existing literature does not explore its advantages specifically to forestry due to none of such literature.

\section{Study Area and Methodology}

\subsection{Study Area}

The study area is Atebubu Forest District which is one of the six forest districts in the Brong-Ahafo Region and has Atebubu as its administrative capital. It is bordered to the north by East Gonja District in the Northern Region and to the south by Ejura-Sekyeredumasi District in the Ashanti Region. To the east, it shares boundaries with the Sene District and to the west with Kintampo and Nkoranza Districts, all in the Brong-Ahafo Region. The Atebubu Forest District has four political districts and are Atebubu-Amantin, Pru, Sene East and Sene West.

\subsection{Methodology}

The study was conducted among all the relevant stakeholders within the Atebubu Forest District. According to the Forestry Commission the key stakeholders are the personnel from the Forest Service Division (Management staffs and Field workers), District Assemblies (Planning \& Budget Officers and Assistant Coordinating Directors), Traditional Authorities (Chiefs and the Traditional Council Registrars), Contractors (Contractors and Workforce), Land owners (Owners and Elders of the towns) and the Fringe Communities (Inhabitants of the communities, Unit Committee Members, Local Council Representatives of the towns) of the NFPDP.

A two stage sampling procedure was used to sample the respondents. At the first stage, purposive sampling procedure was used to sample the six (6) participating institutions out of nine (Table 1) while the second stage of the sampling process involved quota sampling in which set target numbers guided the sampling of respondents from sampled participating institutions (Table 2). In all one hundred and ten (110) respondents were sampled for the study.

Table 2. Composition of participants

\begin{tabular}{ll}
\hline Participating institutions & Number of respondents \\
\hline Forestry Commission & 10 \\
\hline District Assemblies & 10 \\
\hline Traditional Authorities & 20 \\
\hline Land owners & 25 \\
\hline Fringe communities & 25 \\
\hline Contractors /labour & 20 \\
\hline Total & 110
\end{tabular}

Author's construct, $201 \overline{5 .}$

\subsection{Analytical Strategy}

A questionnaire was employed as the data gathering technique. The questionnaire consisted of five sections. Section A dealt with the biographical details of the participants, Section B to Section E contained thirty-six (36) items on sectional themes such as natural resource sustainability, assessment of NFPDP, technical competence of the service contractors and the lead implementing agency. A Likert Scale was used to measure these pertinent constructs of the questionnaire. Out of the one hundred and ten (110) copies of self-administered questionnaires submitted to the sampled respondents, one hundred (100) copies were retrieved and found usable for the analysis given a response rate of $90.9 \%$ 
A likert scale was used to indicate the responses from the respondents to measure the natural resource base sustainability, assessment of NFPDP, technical competence of the service contractors, labour force recruited by the contractors and lead implementing agency. The results were presented using percentages, mean values, standard deviations and relative importance index (RII). The mean values, standard deviations as well as the RII were calculated using the five point Likert scale ( $1=$ strongly disagree, $2=$ disagree, $3=$ neutral, $4=$ agree and $5=$ strongly agree). However, for easy presentation, the percentages for strongly disagree and disagree were combined and strongly agree and agree were also combined.

In addition simple regression (OLS) was used to analyse the factors influencing NFPDP in Model 1 while Model 2 evaluates the factors affecting natural resource based sustainability of NFPDP.

Model 1: The regression equation is stated as:

$$
\mathrm{NFPDP}=\beta_{0}+\beta_{1} T+\beta_{2} L+\beta_{3} L A+\varepsilon_{t}
$$

Where:

NFPDP $=$ National Forest Plantation Development Programme (restoring the forest cover)

$\mathrm{T}=$ Technical competence of the service contractors (technical knowhow of contractors)

$\mathrm{L}=$ Labour force recruited by the contractors (how recruitment was done)

LA $=$ Lead implementing agency (monitoring and supervision of contractors)

$\beta_{0}$ is the constant of the intercept and $\varepsilon_{t}$ is the error term. It is expected that a good technical competence of service contractors, labour force recruited by the contractors and the role of the lead implementing agency will have a positive relation with NFPDP.

Model 2: The regression equation is stated as:

$$
\mathrm{SB}=\beta_{0}+\beta_{1} T+\beta_{2} L+\beta_{3} L A+\varepsilon_{t}
$$

Where:

$\mathrm{SB}=$ Natural resource base sustainability (development and protection of natural resources)

$\mathrm{T}=$ Technical competence of the service contractors (technical knowhow of contractors)

$\mathrm{L}=$ Labour force recruited by the contractors (measurement on how recruitment was made)

LA = Lead implementing agency (measurement is on monitoring and supervision of contractors)

$\beta_{0}$ is the constant of the intercept and $\varepsilon_{t}$ is the error term. It is expected that a good technical competence of service contractors, labour force recruited by the contractors and the role of the lead implementing agency will have a positive relation with the natural resource base sustainability.

\section{Results and Discussion}

\section{Explanation of the columns of Tables 3-7}

There is the need to make these explanations to guide our readers to appreciate how it was done. Disagree shown in the tables is the combination of strongly disagree and disagree. Agree shown in the tables is the combination of strongly agree and agree. Neutral is the indifferent feedback from the respondents. SD is the standard deviation which measures the degree of deviation to the theme/statement outline. Mean is the degree of consensus to the theme/statement outline. RII is the relative importance index, the figure in the parenthesis in the tables means the extent to which the factor contributes to the title of the table while the figure outside the parenthesis is whether the respondents agree with the assertion or not.

\section{Socioeconomic characteristics of the respondents}

In all one hundred (100) respondents took part of the study of which seventy-three (73) were males while twenty-seven (27) were females. The majority of the respondents sixty (60) falls within the age range of 31-40 years while thirty (30) respondents were less than or equal to thirty (30) years of age. The other ten (10) respondents are forty years of age or above. The level of education of the respondents within the sampled participating institutions were 50\% Bachelor Degree holders, 20\% Higher National Diploma (HND) holders, 15\% of them have completed High School and the other 15\% were Junior High School (JHS).

\subsection{Natural Resource Base Sustainability}

This section explored respondent's perspective of the NFPDP outsourcing activities and how it affects the natural resource base sustainability. The result is outlined in Table 3 . 
The high mean values corresponding to "agree" on the Likert scale and the low standard deviations explain the degree of consensus to the theme/statement outlined. The highest mean of 4.70 and a relatively low standard deviation of 0.560 imply that respondents agreed that during the outsourcing period (2010, 2011 and 2012) the District Assemblies negotiated with landowners in line with the government policy. This concludes that the District Assemblies played their role significantly to the forest plantation establishment.

More to the point, the respondents indicated that one of the service contractors, African Foresters Brigade was awarded a seedling production contract. A mean score of 4.60 and standard deviation of 0.492 indicate that the respondents acknowledged that the contractor was wholly in charge of seedling production. This was significant and met the expectations of the purpose of outsourcing the seedling production. Again, the respondents indicated that Zoil GH. Ltd was to pay contract labour wages and salaries. The contractor input was ranked the second most significant when it come to the sustainability of the natural resource base with a mean score of 4.60 and standard deviation of 0.667 . It means that there were salaries/wages payment arrangements under the outsourcing which respondents knew of.

However, all the themes outlined were identified as important contributors to the natural resource base sustainability except contractors had surveyed and demarcated the sites; and survival survey which was done by contractors respectively had a mean score of 1.30 and RII of 0.26 ranked $8^{\text {th }}$ and mean score of 1.50 and RII of 0.3 ranked $7^{\text {th }}$ had no agreement from the respondents by their roles in the natural resource base sustainability in the outsourcing activities. As being one of the reasons could be the respondent's inadequate knowledge of the survival survey. Another reason might be that the survival survey is not visible. This is also possible as they believed that this was done by the Forestry Commission.

Table 3. Natural resource based sustainability

\begin{tabular}{|c|c|c|c|c|c|c|c|}
\hline Variable & Disagree & Neutral & Agree & Mean & SD & RII & Rank \\
\hline District assemblies have negotiated with landowners & - & $5(5 \%)$ & $95(95 \%)$ & 4.70 & 0.560 & 0.94 & $1^{\mathrm{st}}$ \\
\hline Forest Services Division has selected the right site & $20(20 \%)$ & - & $80(80 \%)$ & 4.25 & 1.184 & 0.85 & $5^{\text {th }}$ \\
\hline Contractors have surveyed and demarcated the sites & $90(90 \%)$ & $10(10 \%)$ & - & 1.30 & 0.644 & 0.26 & $8^{\text {th }}$ \\
\hline $\begin{array}{l}\text { Forest Services Division has designed the layout for the } \\
\text { plantation }\end{array}$ & - & $20(20 \%)$ & $80(80 \%)$ & 4.30 & 0.785 & 0.86 & $4^{\text {th }}$ \\
\hline Contract labour has cleared the land. & $20(20 \%)$ & - & $80(80 \%)$ & 4.00 & 1.101 & 0.8 & $6^{\text {th }}$ \\
\hline $\begin{array}{l}\text { Seedlings contract was awarded to African Foresters } \\
\text { Brigade by Forest Services Division. }\end{array}$ & - & - & $100(100 \%)$ & 4.60 & 0.492 & 0.92 & $2^{\text {nd }}$ \\
\hline $\begin{array}{l}\text { Zoil Ghana Limited was in charge of the contract } \\
\text { labour wages/salaries. }\end{array}$ & - & $10(10 \%)$ & $90(90 \%)$ & 4.60 & 0.667 & 0.92 & $2^{\text {nd }}$ \\
\hline $\begin{array}{l}\text { Zoil Ghana Limited was mandated to provide logistics } \\
\text { (wellington boots, uniform etc. }\end{array}$ & - & $20(20 \%)$ & $80(80 \%)$ & 4.30 & 0.785 & 0.86 & $4^{\text {th }}$ \\
\hline Planting was done by the contractors & - & - & $100(100 \%)$ & 4.40 & 0.492 & 0.88 & $3^{\text {rd }}$ \\
\hline Survival survey was done by contractors & $80(80 \%)$ & $20(20 \%)$ & - & 1.50 & 0.810 & 0.3 & $7^{\text {th }}$ \\
\hline Fire rides were constructed by contractors. & - & $40(40 \%)$ & $60(60 \%)$ & 4.00 & 0.899 & 0.8 & $6^{\text {th }}$ \\
\hline
\end{tabular}

Source: Fieldwork, 2015.

We think that it is not enough for supply chain players to work cooperatively but also in harmony to achieve the sustainability base of the natural resource which they were contracted to do. It is difficult to understand whether the contractors were not aware of the timelines or the FC does not have effective monitoring system to track them. The sum effect of the above is that for outsourcing to contribute to a sustainable natural resource base then, the various supply chain members must work cooperatively as cited by Heikkila and Cordon (2002). Also Kakabadse and Kakabadse (2002) asserted that if a function is outsourced cost is controlled and quality of service is improved, this is not the case for NFPDP. 


\subsection{Assessment of NFPDP}

This section looked at the assessment of the NFPDP through the lenses of the respondent's perspective of the outsourcing activities. The result is outlined in Table 4.

The highest mean score of 4.70 also has the highest RII with the second lowest standard deviation of 0.461 implies that planting was done during rainy season and on time. This indicates that all planted seedlings did not experience drought. Again, the respondents opined that beating up was carried out during the rainy season. This was indicated by a mean score of 3.20 and RII of 0.64 with a relatively high standard deviation this means that beating up was done without drought. It is a fact that one of the drivers of outsourcing is for the contractors to do it better. In our opinion, Zoil Limited did a good job by planting on time which will put the subsequent activities on track. This was confirmed by Fan (2000) where they said organizations are into outsourcing to accelerate business processes to create a competitive advantage.

On the basis of land acquisition, a mean score of 1.25 and standard deviation of 0.539 were recorded but ranked $9^{\text {th }}$ by RII which indicated that respondents have diverse views but the majority disagree on the theme and concludes that the acquisition of land for the outsourced function was behind schedule. Moreover, respondents were of the view that the time for survey and demarcation was behind schedule hence delayed the subsequent activities of the outsourcing. As to whether the plantations were protected against bush fires, the respondent's views were emphatically stated with a mean score of 1.20 and ranked $10^{\text {th }}$ on the RII which means the plantations were left to the mercy of bush fires. The respondents expressed their view that fire rides were not constructed according to FC standards. This was indicated by a mean score of 1.50 and ranked $8^{\text {th }}$ on RII this concludes that the contractors did not live up to expectation.

Land clearing and peg cutting and pegging were not done on time as indicated by mean scores of 2.5 and 2.45 respectively but ranked $5^{\text {th }}$ and $6^{\text {th }}$ on the RII. This shows that the activities were lagging behind time. The respondents were of the view that tending was not done in all the coupes as indicated with a mean score of 2.10 with corresponding RII of 0.42 which ranked $7^{\text {th }}$. It is important to state that this affected the survival rate in all the coupes; hence the success rate in most of the coupes was also low. Moreover, respondent's expressed their view that fire rides were not constructed according to FC standards, which shows a mean score of 1.50 with RII ranked $8^{\text {th }}$ with 0.3. It concludes that the contractors did not live up to expectation.

Table 4. Assessment of NFPDP

\begin{tabular}{llllllll}
\hline Variable & Disagree & Neutral & Agree & Mean & SD & RII & Rank \\
\hline Acquisition of land was timely & $95(95 \%)$ & $5(5 \%)$ & - & 1.25 & 0.539 & 0.25 & $9^{\text {th }}$ \\
\hline Survey and demarcation was timely & $50(50 \%)$ & $30(30 \%)$ & $20(20 \%)$ & 2.70 & 0.785 & 0.54 & $3^{\text {rd }}$ \\
\hline Land clearing was done on time & $70(70 \%)$ & $10(10 \%)$ & $20(20 \%)$ & 2.50 & 0.810 & 0.5 & $5^{\text {th }}$ \\
\hline Pegging cutting and pegging were timely done & $70(70 \%)$ & $15(15 \%)$ & $15(15 \%)$ & 2.45 & 0.744 & 0.49 & $6^{\text {th }}$ \\
\hline Planting was done on time & - & - & $100(100 \%)$ & 4.70 & 0.461 & 0.94 & $1^{\text {st }}$ \\
\hline Tending was done in all the coupes & $80(80 \%)$ & $10(10 \%)$ & $10(10 \%)$ & 2.10 & 0.835 & 0.42 & $7^{\text {th }}$ \\
\hline Beating up was done during the rainy season & $30(30 \%)$ & $20(20 \%)$ & $50(50 \%)$ & 3.20 & 0.876 & 0.64 & $2^{\text {nd }}$ \\
\hline Fire rides were constructed according to FC standard & $90(90 \%)$ & - & $10(10 \%)$ & 1.50 & 0.927 & 0.3 & $8^{\text {th }}$ \\
\hline The plantations were protected against bush fires & $100(100 \%)$ & - & - & 1.20 & 0.402 & 0.24 & $10^{\text {th }}$ \\
\hline Survival rate was high in all the coupes & $60(60 \%)$ & $20(20 \%)$ & $20(20 \%)$ & 2.60 & 0.804 & 0.52 & $4^{\text {th }}$ \\
\hline
\end{tabular}

Source: Fieldwork 2015.

On the assessment of the NFPDP, contractors failed to meet deadlines and at times not meeting the standards by FC on their contract performance. The implication here is ineffective monitoring and supervision of FC on the contractors defeated the outsourcing objective. Is it because the FC failed to make it clear to all parties, the laid down roles and responsibilities for a positive outsourcing result. In summary, the re-engineering of the plantations activities as stated by Fan (2000) did not accelerate the business of FC and hence no competitive advantage was created for FC. 


\subsection{Technical Competence of the Service Contractors}

This section considers the technical competence of the service contractors and their role in the NFPDP outsourcing activities. The respondents indicated that the contractors did not have the expertise necessary to handle the plantation activities at the various sites; this was confirmed with a mean score of 1.75 and a standard deviation of 1.095 and ranked second on the RII. This concludes that the outsourced function is a core function of FC. According to Beaumont and Sohal (2004), if organization concentrates on its core function it leads to improvement in business focus, increase in competitiveness and leverage of the organization's skills and resources.

Table 5. Technical competence of the service contractors

\begin{tabular}{|c|c|c|c|c|c|c|c|}
\hline Variable & Disagree & Neutral & Agree & Mean & SD & RII & Rank \\
\hline $\begin{array}{l}\text { The contractors have the expertise to handle the } \\
\text { outsourced function at the sites }\end{array}$ & $80(80 \%)$ & $5(5 \%)$ & $15(15 \%)$ & 1.75 & 1.095 & 0.35 & $2^{\text {nd }}$ \\
\hline The contractors have modern technology than FC & $100(100 \%)$ & - & - & 1.20 & 0.402 & 0.24 & $4^{\text {th }}$ \\
\hline $\begin{array}{l}\text { The contractors have supplied the workers with the } \\
\text { needed logistics }\end{array}$ & $90(90 \%)$ & $10(10 \%)$ & - & 1.50 & 0.674 & 0.3 & $3^{\text {rd }}$ \\
\hline $\begin{array}{l}\text { The contractors have paid the workers regularly and } \\
\text { timely }\end{array}$ & $100(100 \%)$ & - & - & 1.75 & 0.435 & 0.35 & $2^{\text {nd }}$ \\
\hline $\begin{array}{l}\text { The contractors produced quality seedlings according to } \\
\text { FC standard (potted and stumps) }\end{array}$ & - & $10(10 \%)$ & $90(90 \%)$ & 4.40 & 0.667 & 0.88 & $1^{\mathrm{st}}$ \\
\hline
\end{tabular}

Source: Fieldwork, 2015.

Furthermore, the respondents were of the view that the contractors did not have modern technology than FC. This manifested with the mean score of 1.20 and standard deviation of 0.402 and RII of 0.24 . This concludes that technology did not motivate FC into outsourcing the plantation function. Again, respondents said that the contract labour did not have the needed logistics to work with and therefore disagreed to the statement that the contractors have supplied the workers with the needed logistics to work. This was evident with a mean score of 1.50 with standard deviation of 0.674 and RII of 0.3 . This also concludes that the workers performance could be hampered by inadequate supply of logistics. Also, the respondent's indicated that the workers were not paid regularly and timely as seen with the mean score of 1.75 with standard deviation of 0.435 and RII of 0.35 . Finally, the respondent's held the opinion that the contractors produced quality seedlings according to FC standard. This was evident with the highest mean score and RII of 4.40 and 0.88 respectively.

It is imperative that how well the supplier performed certain processes relative to competitors must influence the selection of the contractor. This is where the sourcing organisation scrutinises the external providers. It must be noted that outsourcing can be used to obtain key capability to supplement existing capabilities. We are wondering what the outsource intention was, is it cost reduction or performance improvement. NFPDP can benefit from any of the outsource intentions, if the supplier advantages such as economies of scale and experience had a positive influence on the programme but in this case the contractors technical competencies fell short of the standards hence the result. To a large extent, NFPDP did not benefit from the contractors services as expected. This was supported by Brown and Wilson (2005) where they said that outsourcing risks could come from the supplier, the outsourcing organisation or the business environment. There was a confirmation from Lonsdale and Cox (2000) where they stated that losing core activities is the most significant risk of outsourcing.

\subsection{Labour Force Recruited by the Contractors}

The section looked at how labour was recruited and its role in the outsourcing activities. The respondent's did not believe that the contract labour was engaged by the services contractors. A mean score of 1.20 with standard deviation of 1.402 and RII of 0.24 . This concludes that the workers were recruited by another agency for the services contractors. 
Table 6. Labour force recruited by the contractors

\begin{tabular}{|c|c|c|c|c|c|c|c|}
\hline Variable & Disagree & Neutral & Agree & Mean & SD & RII & Rank \\
\hline Contract labour were recruited by the services contractors & $100(100 \%)$ & - & & 1.20 & 1.402 & 0.24 & $4^{\text {th }}$ \\
\hline Workers were physically fit for the work & - & $10(10 \%)$ & $90(90 \%)$ & 4.40 & 0.667 & 0.88 & $2^{\text {nd }}$ \\
\hline $\begin{array}{l}\text { Workers were informed by their employers that they } \\
\text { were contract labour }\end{array}$ & - & $5(5 \%)$ & $95(95 \%)$ & 4.25 & 0.539 & 0.85 & $3^{\text {rd }}$ \\
\hline Workers were selected from the project communities & $10(10 \%)$ & - & $90(90 \%)$ & 4.60 & 0.921 & 0.92 & $1^{\text {st }}$ \\
\hline
\end{tabular}

Source: Fieldwork, 2015.

The respondents were asked to give their opinion of the physical fitness of the contract labour force and they were of the view that the workers were physically fit for the work. A mean score of 4.40 and standard deviation of 0.667 with RII of 0.88 was recorded. This concludes that the recruitment agency did a good work. Jennings (2002) indicated that capability of supplier improves service quality and increases competitive advantage.

Finally, from the field data the respondents were of the view that the workers were selected from the project communities. The mean score of 4.60 and a standard deviation of 0.921 but was the highest on the RII. This shows that the plantation establishment was geared towards rural poverty reduction.

In its entirety, all the themes the labour force recruited did well as expected from the respondents perspective, apart from the service contractors failing to recruit labour force which we think it was not appropriate unless it was part of the contract that the supplier can outsource this activity to a third party. It was refreshing to see that workers were selected from the communities which will receive all the support from the communities for the outsourcing of NFPDP.

\subsection{Role of the Lead Implementing Agency}

This section considered the role of the lead implementing agency in the forest plantation outsourcing in Forestry Commission, Ghana. Based on data collected from the respondents, Forestry Commission played an active role in the outsourcing process. This was confirmed with a mean score of 4.60 for Range supervisor's involvement in monitoring the land clearing and that of FC/FSD monitoring the beating up was highly significant as both themes had the highest RII of 0.92 .

Table 7. Lead implementing agency

\begin{tabular}{llllllll}
\hline Variable & Disagree & Neutral & Agree & Mean & SD & RII & Rank \\
\hline $\begin{array}{l}\text { FC/FSD Range supervisors were involved in monitoring } \\
\text { the land clearing }\end{array}$ & - & - & $100(100 \%)$ & 4.60 & 0.492 & 0.92 & $1^{\text {st }}$ \\
\hline $\begin{array}{l}\text { FC/FSD personnel were monitoring the seedlings } \\
\text { suppliers }\end{array}$ & - & $20(20 \%)$ & $80(80 \%)$ & 4.10 & 0.704 & 0.82 & $3^{\text {rd }}$ \\
\hline $\begin{array}{l}\text { FC/FSD personnel were monitoring the pegging and } \\
\text { planting }\end{array}$ & $5(5 \%)$ & $15(15 \%)$ & $80(80 \%)$ & 4.30 & 0.905 & 0.86 & $2^{\text {nd }}$ \\
\hline FC/FSD monitored the beating up & - & - & $100(100 \%)$ & 4.60 & 0.492 & 0.92 & $1^{\text {st }}$ \\
\hline FC/FSD monitored tending of the coupes & - & - & $100(100 \%)$ & 4.30 & 0.461 & 0.86 & $2^{\text {nd }}$ \\
\hline FC/FSD monitored the ride construction & $60(60 \%)$ & $10(10 \%)$ & $30(30 \%)$ & 2.70 & 0.905 & 0.54 & $4^{\text {th }}$ \\
\hline $\begin{array}{l}\text { FC/FSD selected the right contractors for the outsourced } \\
\text { function }\end{array}$ & $80(80 \%)$ & $20(20 \%)$ & - & 1.60 & 0.804 & 0.32 & $5^{\text {th }}$ \\
\hline
\end{tabular}

Source: Fieldwork, 2015.

The respondents were further asked if Forestry Commission staff monitored the seedlings supplies. A mean score of 4.10 and a standard deviation of 0.704 with RII of 0.82 support the view that FC was actively involved in the outsourcing process. 
Forestry Commission monitored the pegging and planting of the outsourced function. With a confirmation of mean score of 4.30 and a highly significant in terms of importance ranked second. This implies that the lead implementing agency will be on top on issues related to the outsourcing Furthermore, Forestry Commission monitored the tending of the coupes. The respondents opined that the monitoring of the tending of the coupes was effective with a mean score of 4.30 and standard deviation of 0.461 with RII of 0.86 . This implies that the tending of the coupes is the second most significant of the role of the lead implementing agency to the success of the outsourcing.

The only two areas where the respondents felt Forestry Commission relaxed on its monitoring role/duty were fire ride construction and the selection of the right services contractors. On fire rides, the mean score was 2.70 with standard deviation of 0.905 and RII of 0.54 .

On the other hand, the respondents view was that FC did not select the right services contractors. With a mean score of 1.60 and standard deviation of 0.804 , however, selection of the right contractor was regarded as the least significant of the RII which imply that it had a negative impact on the success of the NFPDP outsourcing activity which is indictment on the lead implementing agency role on the outsourcing.

In our view we think it is important to state that outsourcing might not eliminate the need to manage an activity once it is outsourced. Outsourcing normally involves significant changes in the way in which an activity is managed. Most often control is exercised through a contract rather than through direct ownership of assets and employment of staff. It was encouraging to see how FC/FSD played its role to achieve a higher level of performance on supervision and monitoring, to us we were not surprised as the staffs from FC/FSD are into full term employment with key performance indicators to achieve. We believe the management of FC/FSD implemented a strategy to ensure it was aligned with the overall business strategy of the NFPDP programme.

\subsection{Regression Result}

We tried to capture the effect of outsourcing on NFPDP and technical competence, labour force and lead implementing agency on natural resource base sustainability using regression. The regression result for model 1 and model 2 are represented as follows.

Table 8. The effect of outsourcing on the NFPDP

\begin{tabular}{lll}
\hline Variable & Model 1 (coefficient) & Model 2 (coefficient) \\
\hline Constant & 0.341 & -0.539 \\
\hline Technical competence of service contractors & $(2.58)^{* *}$ & $-3.43^{* * *}$ \\
\hline & 1.186 & -0.103 \\
\hline Labour recruited & $16.35^{* * *}$ & -1.20 \\
\hline & -0.176 & 0.436 \\
\hline Lead implementing agency & $-3.15^{* * *}$ & 6.57 \\
\hline & 0.053 & 0.801 \\
\hline$\overline{\boldsymbol{R}}^{2}$ & 0.72 & $9.07^{* * *}$ \\
\hline
\end{tabular}

Source: Authors' Construct (2015)

Note: $* *$ and $* * *$ are significant levels at $5 \%$ and $10 \%$ respectively. Test statistics are shown in parenthesis.

The model one (1) shows the effect on NFPDP. The result evaluated the effect of technical competence, labour force and the effect of lead implementing agency on NFPDP. The result depicts a positive significant relationship between technical competence of service contractors and NFPDP at 1\% significance level. Thus, a unit change in technical competence of service contactors will lead to approximately 1.2 units change in NFPDP in the same direction. On the other hand, technical competence has a negative and insignificant effect on sustainability of NFPDP as shown in model two (2).

Again, the result shows a negative significant effect of labour force recruited by service contractors on NFPDP. However, the result shows a positive significant effect of labour force recruited by service contractors on sustainability of NFPDP. By implication, a unit change in labour force recruited by service contractors will lead to 
0.436 unit change in sustainability of NFPDP in the same direction. The fact that labour force recruited variable leads to decreasing in sustainability is surprising. This can be explained as non-commitment from the staff of the forestry division as initially was thought that recruitment for the outsourcing will be done from within for the staff to get some income but was given to those outside the forestry division. Those who were recruited from outside were not competent enough to achieve or ensure sustainability and the staff of the forestry decided to leave them on their own.

This result is not in alignment with Corbett (2004), who indicated that organisations are driven into making outsourcing decisions because of their desire to accelerate business process re-engineering to create a competitive advantage. Jennings, (2002) said that capability of suppliers drives companies to making outsourcing decisions. He said that this will create room for partnering which has the potential to increase competitive advantage. This is not the case with the result and possibly the sourcing of the supplier might lack certain details on the supplier competencies on the task at hand. The discussion on the result confirmed why increasing technical competency leads to decreasing sustainability, as the respondents indicated that the service contractor lacks the competency for the task.

Though lead implementing agency has a positive relationship with both NFPDP and sustainability of NFPDP, there is no significant effect of lead implementing agency on NFPDP. However, there exists a significant effect of lead implementing agency on sustainability of NFPDP. A high adjusted $\overline{\boldsymbol{R}}^{2}$ of $96 \%$ and $94 \%$ for model one (1) and model two (2) respectively shows how much the regressors explains variations in the dependent variable.

\section{Conclusion and Recommendation}

The objective of this article was to provide a case study related to outsourcing management and its effects on forestry activities of the Atebubu Forest District in Ghana. The research specifically focused on the assessment of the NFPDP, the technical competence of service contractors, contract labour force.

The paper provides evidence from the study which suggests these conclusions of the study:

Based on the analysed data, it is deduced that almost all the activities needed as a precursor in delivering a sustainable natural resource base per the outsourcing agreement were met. It was revealed that land negotiations were done by the District Assemblies. Forest Services Division (FSD) selected the right plantation sites and designed the layout for the plantation. It came out that the award of seedlings contract to African Foresters Brigade and award of contract to Zoil Ghana Limited were transparent.

In assessing the NFPDP it was evident that activities were behind schedule indicating poor performance, this was contributed to the fact that land acquisition was not timely. However, there were strong disagreement on survey and demarcation, land clearing, peg cutting and pegging were not done timely. Interestingly survival rate was high in all the coupes. On the issue on the technical competence of the service contractors, it was revealed that the service contractors were to a large extent incompetent. They went on to say that the contractors do not have the required technology to execute the function. Evidently, field workers did not have the needed logistics from the contractors to perform their duties, and were not paid regularly and timely.

Labour force recruitment especially for the field assistants which is the responsibility of the contractors was not done by them in spite of the fact that wages and salaries were paid to them by the service contractors. On the issue of the lead implementing agency role, it was strongly acknowledge that, Forestry Commission (FC) has played it roles creditably on monitoring by FC Range Supervisors on land clearing, seedlings supplies, peg cutting and pegging; and beating up.

Based on the findings of the study, it is recommended that, Forestry Commission should put in place proper modalities to ensure effective implementation if outsourcing is to be continued. Services contractors should be technically competent to handle outsourced function. Forestry Commission should enhance its monitoring activities. Field assistants' recruitment should be handled by services contractors. However, it would be interesting and insightful for other researchers to use secondary data to compare pre-outsourcing and post-outsourcing activities of NFPDP to assess the benefits or otherwise of the programme since the current research assesses the stakeholder's perspective of outsourcing of NFPDP.

\section{References}

Barthelemy, J. (2003). The hard and soft sides of IT outsourcing management”. European Management Journal 21(5), 539-548. https://doi.org/10.1016/S0263-2373(03)00103-8

Beaumont, N., \& Sohal, A. (2004). Outsourcing in Australia. International Journal of Operation and Production Management, 24(7), 688-700. https://doi.org/10.1108/01443570410541993

Brown, D., \& Wilson, S. (2005). The Black Book of Outsourcing: How to manage the changes, challenges and 
opportunities. Hoboken, New Jersey: John Wiley \& Sons Inc.,

Burkholder, N.C. (2006). Outsourcing: The Definitive View, Applications, and Implications. Hoboken, New Jersey: John Wiley \& Sons, Inc.

Click, R.L., \& Dueing, T.N. (2005). Business Process Outsourcing: The Competitive Advantage. Hoboken, New Jersey: John Wiley \& Sons, Inc.

Clott, C.B. (2004). Perspectives on global outsourcing and the changing nature of work. Business and Society Review, 109(2), 153-170. https://doi.org/10.1111/J.0045-3609.2004.00189.X

Corbett, M.F. (2004). The Outsourcing Revolution. Why it makes sense and how to do it right. Chicago: Dearborn Trading Publishing.

Fan, Y. (2000). Strategic Outsourcing: Evidence from British Companies. Marketing Intelligence and Planning, 18(4), 213-219. https://doi.org/10.1108/02634500010333398

Gonzalez, R., Gasco, J., \& Llopis, J. (2005). Information systems outsourcing reasons in the largest Spanish firms. International Journal of Information Management, 25(2), 117-136. https://doi.org/10.1016/j.ijinfomgt.2004.10.002

Heikkila, J., \& Cordon, C. (2002). Outsourcing: a core or non-core strategic management decision? Strategic Change 11(4), 183-193. https://doi.org/10.1002/jsc.589

Heywood, J.B. (2001). Outsourcing Dilemma: The Search for Competitiveness. Harlow: FT: Prentice Hall.

Hoetker, G. (2005). How much you know versus how well I know you. Selecting a supplier for a technically innovative component. Strategic Management Journal, 26(1), 75-96. https://doi.org/10.1002/smj.453

Jennings, D. (2002). Strategic Outsourcing: Benefits, problems and a contextual model. Management Decision, 40(1), 26-34. https://doi.org/10.1108/00251740210413334

Kakabadse, N., \& Kakabadse, A. (2002). Trends in outsourcing: contrasting USA and Europe. European Management Journal, 20(2), 189-198. https://doi.org/10.1016/S0263-2373(02)00029-4

Lonsdale, C., \& Cox, A. (2000). The historical development of outsourcing: the latest fad? Industrial Management and Data Systems, 100(9), 444-450. https://doi.org/10.1108/02635570010358384

McIvor, R. (2005). The Outsourcing Process: strategies for evaluation and management. Cambridge: Cambridge University Press.

Mikkola, J.H. (2003). Modularity, component outsourcing and inter-firm learning. $R \& D$ Management, 33(4), 439-454. https://doi.org/10.1111/1467-9310.00309

Mikkola, J.H. (2006). Capturing the degree of modularity embedded in product architectures. Journal of Product Innovation Management, 23(2), 128-146. https://doi.org/10.1111/j.1540-5885.2006.00188.x

Mol, M.J.M., Mathlyssens, P., Pauwels, P., \& Quintens, L. (2004). A technological contingency perspective on the depth and scope of international outsourcing. Journal of International Management, 10(2), 287-305. https://doi.org/10.1016/j.intman.2004.02.005

Morgan, R.E. (2003). Outsourcing: Towards the 'shamrock organization. Journal of General management, 29(2), $35-52$

Platz, L.A., \& Temponi, C. (2007). Defining most desirable contract between customer and vendor. Management Decision, 45(10), 1656-1666. https://doi.org/10.1108/00251740710838013

Quelin, B., \& Duhamel, F. (2003). Bringing together strategic outsourcing and corporate

Strategy: Outsourcing motives and risks. European Management Journal, 21(5), 647-661. https://doi.org/10.1016/S0263-2373(03)00113-0

Weerakkody, V., \& Curries, W.L. (2003). Re-engineering business processes through application service $\begin{array}{lllll}\text { providers. Business Process Management Journal, 9(6), } & \text { 776-794. }\end{array}$ https://doi.org/10.1108/14637150310506693

\section{Copyrights}

Copyright for this article is retained by the author(s), with first publication rights granted to the journal.

This is an open-access article distributed under the terms and conditions of the Creative Commons Attribution license (http://creativecommons.org/licenses/by/4.0/). 